\title{
Manhaj Dakwah Nabi Ibrahim a.s. Menurut al-Qur'an dan Aplikasinya dalam Dakwah Masa Kini
}

\author{
Rohaily @ Abd Rahman Abd Hamid \\ Universiti Malaya, haily5477@gmail.com \\ Nor Raudah Hj. Siren \\ Universiti Malaya, raudah68@um.edu.my
}

\begin{abstract}
Abstrak
Manhaj dapat difahami sebagai kaedah, metode, cara atau uslub. Bermaksud jalan yang menjelaskan dan menyampaikan kepada sesuatu perkara. Justeru, manhaj adalah sesuatu yang penting untuk difahami dan dipraktikkan bagi menjayakan sesuatu matlamat. Apatah lagi manhaj dalam berdakwah yang merupakan jentera penggerak kejayaan tugas tinggalan para rasul ini. Jika baik dan tepat sesuatu manhaj maka akan baik dan eloklah penghasilannya. begitulah sebaliknya. Lantaran itu kertas ini bertujuan untuk memaparkan manhaj yang digunakan oleh Nabi Ibrahim a.s. ketika berdakwah kepada kaumnya sebagaimana yang dinyatakan di dalam Al-Qur'an. Metode kajian yang dilakukan menggunakan metode analisis kandungan terhadap beberapa surah yang berkaitan dengan kisah Nabi Ibrahim a.s. di dalam Al-Qur'an. Selaku 'Abb al-anbiyā'(bapa kepada para nabi), baginda wajar dirujuk dalam merealisasikan usaha-usaha dakwah khasnya yang berkaitan teknik dan manhaj dakwah. Terdapat beberapa manhaj yang diaplikasikan dalam dakwah baginda. Apa yang dibentangkan di sini adalah dapatan dari AlQur'an yang memaparkan keunggulan baginda dalam menyampaikan dakwah kepada semua peringkat umat manusia, bermula dari bapa baginda, kaum dan penguasa di zaman tersebut. Paparan manhaj dakwah Nabi Ibrahim a.s. menerusi Al-Qur'an ini juga turut digunakan oleh pendakwah masa kini sebagai gambaran dan garis panduan kepada para daie untuk menyempurnakan tugas mulia warisan tinggalan para rasul.
\end{abstract}

Kata kunci: Manhaj dakwah, uslub dakwah, metode dakwah, Nabi Ibrahim, manhaj dakwah al-Qur'an

\section{The Preaching Manhaj of Prophet Ibrahim (a.s.) According to the al-Quran and Its Application in the Present Da'wah}

\begin{abstract}
Manhaj may be understood as the technique, method, manner or uslub. It means the route which explains and brings us to a particular matter. Therefore, manhaj is something important to be understood and practiced in order to secure the results. It is especially important when we apply manhaj in preaching activities, which is the main force in ensuring the legacy of the prophets is continued. If the manhaj is good
\end{abstract}


and proper, then the results would turn out good too, and vice versa. Therefore, this paper is meant to disclose the manhaj used by Prophet Ibrahim (a.s.) when he preached to his people, as described in the alQuran. The method used for this research was an analysis of the contents of several chapters, or surahs, which provided accounts regarding Prophet Ibrahim (a.s.) in the al-Quran. As the 'Abb al-anbiyā', or father of prophets, he is the most apt to be studied when we want to accomplish our preaching efforts, especially those regarding techniques and preaching manhaj. Many types of manhaj were applied in his preaching efforts. The manhaj discussed here are taken from the Al-Quran, and illustrate the excellence in his efforts to preach to all levels of mankind, from his own father, to his people and to the authorities during his time. The manhaj of da'wah of the Prophet Ibrahim a.s. through this Qur'an is also used by present preachers as an illustration and guidance to the daie to complete the glorious task of the legacy of the apostles.

Keywords: preaching manhaj, uslub da'wah, preaching methods, Prophet Ibrahim, preaching manhaj in the al-Quran

\section{Pendahuluan}

Manhaj adalah kalimah yang berasal daripada Bahasa Arab yang bererti kaedah atau cara. Ia juga seerti dengan kalimah uslub. ${ }^{1}$ Ibnu Fāris menyatakan kalimah ini membawa dua makna. Pertama, manhaj bererti jalan yang menjelaskan sesuatu perkara. Kedua, perhentian yang menunjukkan laluan yang jelas dan nyata. ${ }^{2}$ Kalimah manhaj juga disebut minhāj sebagaimana firman Allah S.W.T.:

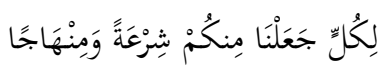

al-Māidah 5: 48.

Terjemahan: Bagi setiap umat Kami jadikan satu syariat dan jalan (agama yang wajib diikuti).

Berdasarkan ayat di atas, Al-Qur'an adalah kitab Allah yang diturunkan untuk membawa petunjuk kepada umat Islam. Nabi Ibrahim merupakan antara Rasul yang ditugaskan oleh Allah utnuk menyampaikan Islam kepada kaumnya berdasarkan manhajnya yang tersendiri sesuai dengan mad'u. Justeru itu, manhaj dakwah Nabi Ibrahim a.s. bermaksud cara dan kaedah yang jelas

1 Noresah Baharom, et al., Kamus Dewan Edisi Keempat, cet. ke-2 (Kuala Lumpur: Dewan Bahasa dan Pustaka, 2007), 994 entri "manhaj".

2 Aḥmad bin Fāris al-Qazwin̄̄, Maqūyīs al-Lughah, tahq. "Abd al-Salām Muḥammad Hārūn (Beirut: Dār al-Fikr, 1979), 5: 361, entri “nahj”. 
dipraktikkan oleh baginda dalam menyampaikan dakwah. Sudah pasti manhaj dakwah baginda yang dipaparkan di dalam AlQur'an bertujuan untuk membei pedoman dan teladan kepada umat Islam khususnya para pendakwah dalam menyempurnakan tanggungjawab menyampaikan risalah Allah.

\section{Manhaj Dakwah Nabi Ibrahim a.s.}

Al-Qur'an banyak menceritakan kisah dakwah Nabi Ibrahim a.s. yang memaparkan pelbagai manhaj yang digunakan untuk menjayakan dakwah baginda. Kepelbagaian manhaj ini dilakukan bagi memenuhi keperluan dakwah yang berhadapan dengann sasaran dan situasi dakwah yang berbeza-beza. Di antara manhaj yang digunakan secara praktikal ialah:

i. Menjadikan diri sebagai Qudwah (Teladan yang Baik) Nabi Ibrahim sentiasa menampilkan dirinya sebagai qudwah; teladan yang baik untuk diikuti. Malah ia menjadi manhaj asasi dalam dakwah baginda. Qudwah bermaksud contoh kepada sesuatu untuk ditiru dan dirujuk agar menjadi sama seperti yang ditiru. ${ }^{3}$ Ini bererti qudwah adalah suatu keadaan pada diri seorang insan yang menjadi ikutan insan lain sama ada baik atau buruk, bermanfaat atau memberi mudharat. Allah S.W.T juga telah memilih baginda untuk menjadi rujukan dan ikutan para nabi dan rasul. Baginda juga menjadi qudwah dan teladan kepada para pendakwah dalam menyampaikan risalah Allah. Allah bersaksi tentang ketokohan baginda melalui firmanNya:

$$
\text { وَإِبْرَاهِيمَ الَّذِي وَفَّنَ }
$$

al-Najm 53: 37.

Terjemahan: Dan Ibrahim yang telah memenuhi dengan sempurna (segala yang diperintahkan kepadanya).

Pujian ini diberikan kepada Nabi Ibrahim kerana telah terbukti baginda sentiasa berjaya menyempurnakan segala perintah Allah dan memastikan diri menjadi qudwah kepada manusia selepas baginda. Lantaran kejayaan baginda menjadi qudwah dalam menegakkan kebenaran dan menyempurnakan perintah dan

3 Aḥmad bin Fāris al-Qazwīnī, Maqāȳiss al-Lughah, Taḥqīq: 'Abd al-Salām Muḥammad Hārūn, (Beirut: Dār al-Fikr, 1979M-1399H), 5: 66, entri “قود". 
tanggungjawab, Allah s.w.t telah melantik baginda sebagai imam ikutan sekalian manusia. Perhatikan firman Allah S.W.T. berikut:

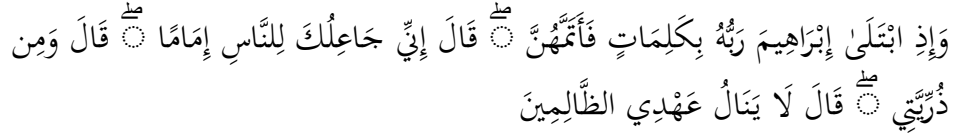

al-Baqarah 2:124.

Terjemahan: Dan ingatlah ketika Ibrahim diuji oleh Tuhannya dengan beberapa perintah, lalu dia pun menyempurnakannya. Allah berfirman, "Sesungguhnya aku menjadikan kamu imam (ikutan) bagi umat manusia."

Bahkan setiap rasul yang diutuskan oleh Allah s.w.t selepas Nabi Ibrahim a.s. membawa ajaran dan manhaj dakwah yang sama dengan apa yang dibawa oleh baginda sehinggalah perutusan nabi terakhir, Nabi Muhammad s.a.w. Ketokohan Nabi Ibrahim sebagai suri teladan dinyatakan oleh Allah di dalam firmanNya:

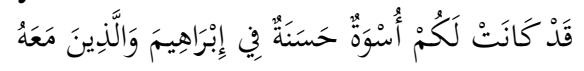

al-Mumtaḥanah 60: 4.

Terjemahan: Sesungguhnya adalah untuk kamu suri teladan yang baik pada diri Nabi Ibrahim dan mereka yang bersama baginda.

Ayat di atas menjelaskan tentang dorongan untuk mencontohi Nabi Ibrahim dalam semua perkara yang dilakukan dan mereka yang beriman bersama baginda. ${ }^{4}$ Ternyata bahawa ketokohan baginda sebagai uswah hasanah; suri teladan kepada umat Islam dalam kehidupan diperakukan oleh Allah S.W.T di dalam AlQur'an, termasuklah manhaj baginda dalam berdakwah Justeru, sewajarnya setiap pendakwah menjadikan baginda sebagai tokoh pendakwah yang diteladani bagi memastikan kejayaan usahausaha dakwah yang dijalankan.

ii. Berlembut dalam Berdakwah

Berlembut dalam menyampaikan risalah Allah adalah suatu perlakuan yang terpuji. Bahkan ia suatu tuntutan bagi menjamin dakwah yang berkesan. Sebuah hadith Rasulullah s.a.w. menegaskan displin ini:

4 Fakhr al-Dīn al-Rāzī, Mafātīh al-Ghayb al-Tafsīr al-Kabīr (Beirut: Dār Iḥyā' al-Turāth al-'Arabiyy, 1999), 29: 250. 


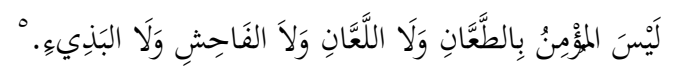

Terjemahan: Bukanlah seorang beriman itu pencela, pengutuk, bercakap kotor dan mencarut.

Inilah perintah Allah kepada para rasul yang berjaya dilaksanakan oleh Nabi Ibrahim a.s. sebagai satu manhaj dalam menyeru manusia kepada Allah. Firman Allah s.w.t:

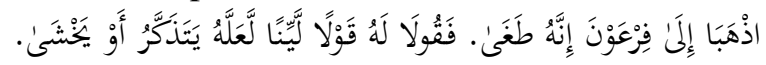

Ṭāhā 20: 43-44.

Terjemahan: "Pergilah kamu berdua (Musa dan Harun) kepada Firaun, sesungguhnya dia telah melampaui batas dalam kekufurannya. Kemudian hendaklah kamu berkata kepadanya dengan kata-kata yang lembut, semoga dia beringat atau takut."

Ayat di atas menjelaskan bahawa Allah memerintahkan Nabi Musa dan Nabi Harun adalah berbicara dengan lembut dan lunak agar dapat memberi kesan di jiwa dan lebih menjayakan usahausaha dakwah. Berbicara dengan lembut mampu melunakkan hati penderhaka dan mampu meruntuhkan tembok keegoan orang sering melakukan dosa. ${ }^{6}$ Biarpun ia tidak boleh digunakan pada semua situasi namun dakwah perlu dimulakan dengan manhaj berbicara secara lembut ini. Ia adalah suatu manhaj yang terbukti dapat memujuk dan meruntun hati orang yang diseru. Kebiasaannya kelembutan itu boleh melenyapkan kekasaran, kesombongan dan ia boleh membuka pintu hati sasaran. ${ }^{7}$ Kelembutan Nabi Ibrahim dalam dakwah dilihat dengan penggunaan bahasa dan ungkapan kata yang melambangkan

\footnotetext{
5 Hadith riwayat al-Tirmidhī daripada 'Abdullāh ibnū Mas'uūd r.a, Muhammad bin 'Īsā bin Sawrah bin Mūsā bin al-Ḍaḥhāq, Abū 'Īsā, Al-Jāmi' al-Kabīr, Sunan al-Tirmidhī, (Beirut: Dār al-Gharb al-Islāmī, 1998) no. hadith 1977, 3:418, Ibnu Ḥibbān, Muḥammad Ḥibbān bin Aḥmad bin Ḥibbān bin Mu'adh bin Ma'bad al-Tamīmī, Abū Ḥātim, Saḥ̄ị Ibnu Hibbān (Beirut: Muassasah alRisālah, 1993), no. hadith 192, 1:421. Al-Tirmidhī mengatakan hadith ini bertaraf hasan gharī̄b.

6 Aḥmad bin Muștafā al-Marāghī, Tafsīr Al-Marāgh̄̄ (Mesir: Sharikah Maktabah wa Mațba'ah Mușțafā al-Bābī Al-Ḥalabī wa Aulādihi, 1946), 16: 114.

7 Ab. Aziz Mohd. Zin, Psikologi Dakwah (Kuala Lumpur: Jabatan Kemajuan Islam Malaysia, 1999), 50.
} 
perasaan bimbang dan belas kasihan baginda kepada insan yang diseru. Perhatikan firman Allah S.W.T. berikut:

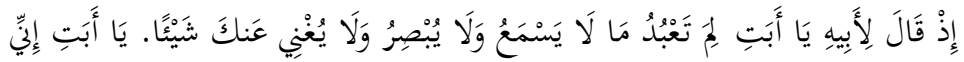

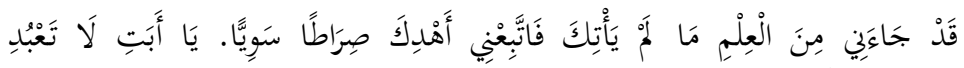

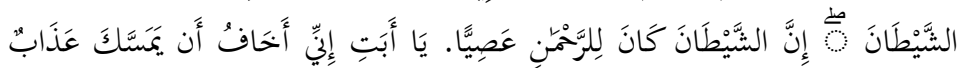

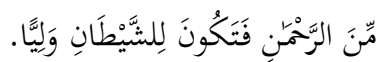

$$
\begin{aligned}
& \text { Maryam 19: 42-45 }
\end{aligned}
$$

Terjemahan: Ketika dia (Ibrahim) berkata kepada bapanya: "Wahai ayahku, mengapa ayah menyembah benda yang tidak mendengar dan tidak melihat serta tidak dapat menolongmu sedikitpun? Wahai ayahku, sesungguhnya telah datang kepadaku ilmu pengetahuan yang tidak pernah datang kepadamu, oleh itu ikutilah aku, akan kupimpinmu ke jalan yang benar. Wahai ayahku, janganlah ayah menyembah Syaitan, sesungguhnya Syaitan itu telah menderhaka kepada Allah yang melimpah-ruah rahmatNya. Wahai ayahku, sesungguhnya aku bimbang bahawa ayah akan terkena azab dari (Allah) Ar-Rahman maka dengan sebab itu ayah akan menjadi rakan bagi Syaitan (di dalam neraka).

Dalam ayat ini kita dapat melihat bagaimana Nabi Ibrahim menggunakan pendekatan memupuk jiwa insan agar beriman dalam dakwah baginda. Manhaj yang indah dalam berdialog dan berdebat yang menggabungkan perasaan kasih, belas kasihan, simpati dan ketenangan. Meskipun baginda menentang kekufuran yang digenggam bapanya dan menyerunya agar beriman, namun lihatlah bagaimana setiap kalimah yang dilafazkan dalam seruan baginda ternyata sarat dengan perasaan kasih dan harapan agar kebaikan dan keselamatan sampai kepada bapanya. ${ }^{8}$

Setelah terbukti cara berlembut tidak berjaya memberi kesan, barulah baginda memilih untuk menggunakan cara yang keras untuk menyatakan kebenaran dengan lebih serius. Manhaj berkeras yang pernah digunakan oleh Nabi Ibrahim ini hanya diaplikasikan apabila uslub berlembut tidak berjaya mengajak golongan yang didakwah untuk menerima risalah Allah. Baginda berkeras untuk menyedarkan mereka atas tuntutan untuk

8 Șalāh Abd al-Fattāḥ Al-Khālidī. Al-Qașaṣ al-Qur'ān̄̄ (Damsyik- Syria: Dār alQalam, 1998) 1:319. 
menyedarkan dan menyelamatkan mereka dari lembah kesesatan. Antara tindakan berkeras yang baginda lakukan ialah dengan mencemuh cara menilai dan berfikir bapanya dan kaumnya dalam menentukan tuhan yang sewajarnya disembah. Inilah yang dinyatakan oleh Al-Māturidī ketikan mentafsirkan firman Allah S.W.T. berikut:

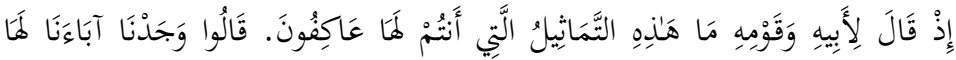

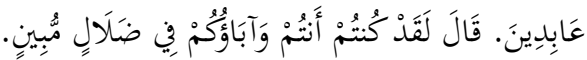

$$
\begin{aligned}
& \text { al-Anbiyā' 21: 52-54. }
\end{aligned}
$$

Terjemahan: Ketika dia (Ibrahim) berkata kepada bapanya semua yang kamu bersungguh-sungguh memujanya? dan kaumnya: "Apakah sebenarnya patung-patung ini Mereka menjawab: "Kami dapati datuk nenek kami selalu menyembahnya." Dia berkata: "Sesungguhnya kamu dan datuk-nenek kamu adalah dalam kesesatan yang nyata."

Beliau mengulas; ${ }^{9}$ Baginda seolah-olah berkata: "Apakah semua berhala-berhala yang kamu ambil sebagai tuhan, kamu beriktikaf serta beribadah kepadanya? Sewajarnya sembahan dilakukan oleh makhluk kepada siapa yang menciptakannya. Sudahkah kamu berfikir sehingga nampak gunanya benda-benda yang kamu sembah itu? Namun sebaliknya jika sembahan makhluk adalah apa yang diciptanya sendiri, ia tidak dapat diterima akal. Justeru baginda berkata, "Apakah patut kamu sembah apa yang kamu ukir? Sedangkan Allah yang menciptakan kamu dan apa yang kamu lakukan." Baginda menyatakan kebodohan mereka dan memperlihatkan keaiban mereka menyembah apa yang mereka mereka ukir dengan tangan mereka sendiri dan meninggalkan sembahan kepada yang menciptakan mereka dan perbuatan mereka. Sungguh terhenti hujah mereka dengan apa yang dikatakan Nabi Ibrahim dan menzahirkan kebodohan mereka.

Gaya bahasa Nabi Ibrahim yang keras dalam ayat ini adalah semata-mata untuk menyampaikan hak Allah S.W.T. Berbicara dengan sebegini tegas dan keras hanya boleh dilakukan setelah terbukti manhaj berlembut yang digunakan terlebih dahulu tidak

Abū Manșūr Muḥammad bin Muḥammad bin Maḥmūd al-Māturidī, Ta'wīlāt Ahli al-Sunnah Tafsīr Al-Māturīd̄̄ (Beirut: Dār al-Kutub Al-'Ilmiyah, 2005), 7: 352-353 
berhasil. Sungguhpun penghormatan kepada bapa dan kaum kerabat adalah suatu hak yang perlu dipelihara, namun ia tetap tidak boleh mengatasi hak Allah S.W.T. yang menjadi asas risalah dakwah. Inilah yang dijelaskan oleh Al-Māturidī ${ }^{10}$ apabila kaum Nabi Ibrahim apabila mereka mengatakan; "Kami dapati datuk nenek kami selalu menyembahnya." Inilah yang perlu disedari dan dilakukan oleh setiap para daie tatkala berlaku pertembungan di antara dua kepentingan yang perlu dijaga. Hak Allah S.W.T. perlu sentiasa dijulang dan dipelihara sepanjang masa.

\section{iii. Memulakan Dakwah Kepada Kaum Kerabat Terdekat}

Manhaj yang jelas diamalkan oleh Nabi Ibrahim dalam dakwah baginda ialah memulakan dakwah kepada kaum kerabat yang terdekat iaitu bapanya sendiri. Menerusi Al-Qur'an kita dapat melihat betapa baginda menyusun langkah-langkah dakwah dengan begitu teratur dan sempurna secara berperingkat. Baginda memulakan dakwah kepada insan yang paling hampir dengan baginda iaitu bapanya sebelum berdakwah kepada kaumnya dan pemerintah di negeri baginda. Hakikatnya ini adalah hak setiap individu yang memulakan sesuatu kebaikan dengan dirinya, kemudian ahli keluarganya, setelah itu kaum kerabatnya, masyarakat sekeliling dan begitulah seterusnya. Inilah juga tradisi dakwah para rasul yang sewajarnya diteladani. Al-Qurtubi menyebut; "Menyempurnakan hak kaum kerabat adalah keutamaan sebelum orang lain dalam menyelamatkan mereka daripada syirik dan kekufuran."11 Bahkan manhaj ini adalah perintah Allah sebagaimana yang termaktub di dalam Al-Qur'an, al-Shu'arā': 214,

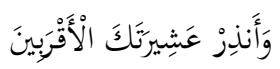

Al-Shu'arā’ 26:214

Terjemahan: "Dan berilah peringatan kepada kaum kerabatmu yang terdekat."

Hal ini disokong oleh Al-Rāzi yang mengulas tentang keperluan manhaj dakwah ini dengan katanya, "Apabila seseorang memulakan kesungguhan dakwah pada dirinya kemudian kerabat

${ }^{10}$ Al-Māturidī, Ta 'wìlāt Ahli al-Sunnah Tafsīr Al-Māturīdī, 7: 352-353

${ }^{11}$ Muḥammad bin Aḥmad bin Abū Bakr al-Qurțub̄i, Al-Jāmi' li Aḥkām al-Qur'ān (Kaherah: Dār al-Kātib al-‘Arabī li al-Ṭibā’ah, 1966), 13:143. 
terdekat, setelah itu kerabat yang jauh dan seterusnya begitu, tiada sesiapa yang mengecamnya atau mengingkarinya bahkan perkataannya akan lebih bermanfaat dan bicaranya pula akan lebih berkesan." 12

\section{iv. Memberi Amaran dan Ancaman}

Setelah nyata cara berlembut dan berbahasa keras tidak juga memberi kesan, manhaj memberi amaran dan ancaman dan berhadapan dengan penentang perlu dilakukan. Ia pernah dilakukan oleh Nabi Ibrahim ketika berhadapan dengan kedegilan kaumnya yang tegar dengan kesyirikan setelah terbukti kebenaran dan hujah yang dibawakan kepada mereka. Cara ini hanya boleh diaplikasikan setelah usaha-usaha dakwah yang awal secara berdialog, berhujah dan berdebat dibuat. Inilah yang dinyatakan oleh Al-Qurțubī ketika mengulas amaran Nabi Ibrahim a.s, terhadap kaumnya di dalam firman Allah S.W.T.:

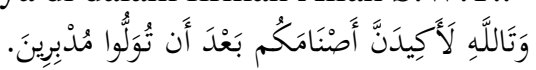

al-Anbiyāa 21: 57.

Terjemahan: Dan demi Allah, akan aku jalankan rancangan terhadap berhala-berhala kamu, sesudah kamu pergi meninggalkan (rumah berhala ini).

Baginda mengancam untuk menghancurkan berhala-berhala sembahan kaumnya. Baginda melakukannya sesuai dengan kedegilan dan keangkuhan mereka menolak kebenaran yang telah terbukti di hadapan mereka. Baginda bertekad dengan bersumpah melakukannya demi memperjuangkan agama Allah tanpa memikirkan apa jua risiko yang akan diterima. ${ }^{13}$

\section{v. Bertindak Selaras Percakapan}

Kemampuan bertindak selaras dengan pedoman dakwah dan syariat adalah kejayaan besar bagi seorang pendakwah. Bahkan Rasulullah s.a.w. pernah menegaskan kepentingan menggunakan 'kuasa bertindak' dalam berdakwah bagi mencapai tahap keimanan terbaik. ${ }^{14}$ Baginda menyatakan tentang kepentingan

${ }^{12}$ Fakhr Al-Dīn Al-Rāzī, Mafātīh al-Ghayb al-Tafsīr al-Kabīr (Beirut: Dār Iḥyā' al-Turāth Al-'Arabī, 1999), 24: 172.

13 Al-Qurțubī, Al-Jāmi' li Aḥkām al-Qur'ān, 7: 111.

${ }^{14}$ Hadith masyhur riwayat Muslīm daripada Abū Sa‘̄id al-Khuḍrī. Lihat Muslim bin al-Ḥajjāj abu al-Ḥasan al-Qushairī al-Naisābūrī, Șahịh Muslim, taḥqīq 
setiap muslim perlu bertindak mencegah kemungkaran dengan tangannya jika dia mampu melakukannya. Inilah manhaj yang digunakan oleh Nabi Ibrahim a.s. dalam dakwah baginda. Ketegasan dan keberanian baginda dalam menegakkan kebenaran dibuktikan dengan manhaj ini lalu bertindak memusnahkan berhala-berhala sembahan kaumnya. Lihatlah bagaimana Allah S.W.T. menceritakan tindakan baginda ini di dalam ayat-ayat berikut:

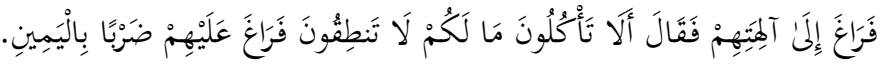

al-Ṣāffāt 37: 91-93

Terjemahan: Maka dia pergi kepada berhala-berhala mereka lalu bertanya: "Mengapa kamu tidak makan? Mengapa kamu tidak menjawab?" Lalu dia memukul berhala-berhala itu dengan tangan kanannya.

Ternyata manhaj ini hanya mampu dilaksanakan oleh para pendakwah yang benar-benar memiliki keyakinan dan keimanan yang tinggi. Lantaran ia pasti mengundang tentangan, ancaman dan risiko yang besar pada pelakunya. Lalu, kemampuan mereka memperjuangkan dakwah dengan manhaj ini didukung oleh kekuatan tawakal dan mengharapkan keredhaan Allah S.W.T. Lihatlah apa yang terpaksa diterima oleh Nabi Ibrahim setelah tindakan berani baginda memecahkan berhala-berhala tersebut. Namun keyakinan dan tawakal baginda amat tinggi. Meskipun setelah ditangkap dan dicampak ke dalam api, baginda tetap berhadapan dengan semua itu dengan tenang dan yakin kepada kekuasaan Allah S.W.T. Baginda dengan penuh yakin dan tawakal mengucapkan 'Hasbunā Allāhu wa ni'ma al-Wakīl' ketika dicampak ke dalam api. ${ }^{15}$

Muḥammad Fuād 'Abd al-Bāqī (Beirut: Dār Iḥyā Al-Turāth Al-'Arabī, (t.t.) no. hadith 49, 1:69, lafaznya:

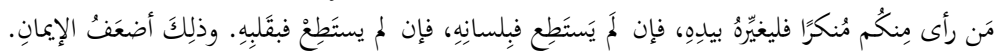

${ }^{15}$ Șalāh Abd al-Fattāḥ Al-Khālidī. Al-Qașaș al-Qur'ān̄̄ (Damsyik-Syria: Dār alQalam, 1998),1:362, Hadith riwayat al-Bukhārī daripada Ibn 'Abbās r.a. Lihat Muhammad bin Ismā‘n̄l al-Bukhārī, Șaḥ̄ḥ Al-Bukhārī (Beirut: Dār Ṭūq alNajāh, 2001), 6:39, no: 4563, lafaz hadith:

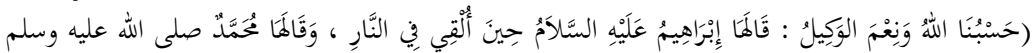

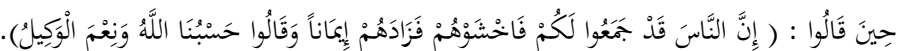


vi. Berhujah dengan bijak dan berani

Setelah kaumnya menyedari berhala-berhala sembahan mereka hancur dimusnahkan oleh Nabi Ibrahim mereka bergegas mendapatkan baginda untuk meminta penjelasan dan bertindak balas ke atas perlakuan itu. Ketika berhadapan kaumnya yang sedang marah, Nabi Ibrahim tetap tenang dan masih mampu mengajak kaumnya berhujah dengan menggunakan rasional. Inilah suatu manhaj yang dipamerkan oleh baginda yang menggambarkan ketokohan baginda sebagai seorang utusan Allah. Firman Allah:

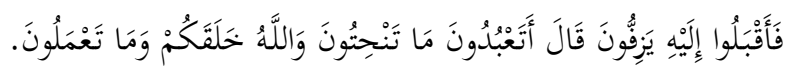

al-Ṣāffāt 37: 94-96.

Terjemahan: Maka datanglah kaumnya beramai-ramai kepadanya. (Menjawab bantahan mereka), dia berkata: "Patutkah kamu menyembah benda-benda yang kamu pahat? Padahal Allah yang mencipta kamu dan benda-benda yang kamu buat itu!"

Hamka mengulas kebijaksanaan Nabi Ibrahim dengan dalam tafsirnya, "Ibrahim telah mengemukakan pertanyaan. Dengan terus terang kaumnya menjawab bahawa sembahan mereka adalah berhala yang selalu kami puja dan beriktikaf di sekelilingnya. Hal ini akan tetap kekal selama-lamanya. Lalu Ibrahim mengajak kaumnya menggunakan fikiran untuk menilai semula tindakan mereka." $" 16$

Bahkan baginda sempat lagi menyindir mereka dengan ungkapan yang mengajak mereka berfikir tentang kewajaran apa yang mereka pilih sebagai sembahan. Firman Allah:

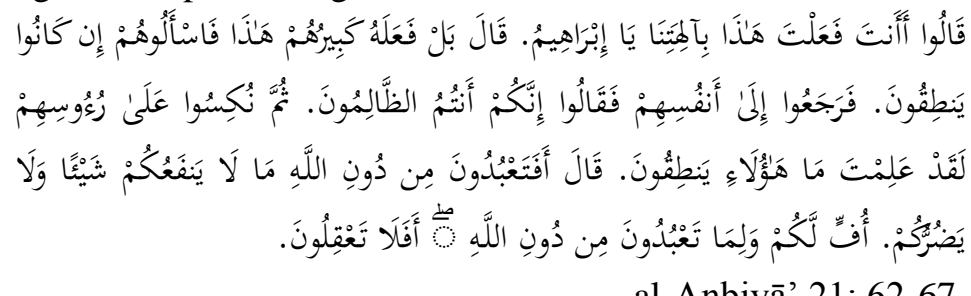

Terjemahan: Mereka bertanya: "Engkaukah yang melakukan ini kepada tuhan-tuhan kami, wahai Ibrahim?" Dia

\footnotetext{
${ }^{16}$ Haji Abdul Malik Abdul Karim Amrullah, Tafsir al-Azhar (Singapura: Pustaka Nasional Pte. Ltd., 1990), 7: 5114.
} 
menjawab: "Bahkan yang melakukannya (berhala) yang besar di antara mereka ini! maka tanyalah kepada mereka jika mereka dapat berkata-kata". Maka mereka kembali kepada diri mereka (memikirkan hal itu) lalu berkata (sesama sendiri): "Sesungguhnya kamulah orang yang zalim". Kemudian mereka berbalik kepada kesesatan, lalu berkata: "Sesungguhnya kamu telah mengetahui bahawa berhalaberhala itu tidak dapat berkata-kata." Nabi Ibrahim berkata: "Jika demikian, patutkah kamu menyembah yang lain dari Allah sesuatu yang tidak dapat mendatangkan faedah sedikitpun kepada kamu, dan juga tidak dapat mendatangkan mudarat kepada kamu? Jijik perasaanku terhadap kamu dan apa yang kamu sembah selain Allah! Maka mengapa kamu tidak mahu menggunakan akal fikiran?"

\section{vii. Berhijrah}

Manhaj ini dilaksanakan oleh Nabi Ibrahim setelah nyata segala usaha, laluan dan ruang untuk menyampaikan dakwah tertutup rapat di tanah air baginda. Baginda membuat keputusan ini demi mempertahankan risalah Allah dan terus memperjuangkannya di medan baru. Hijrah yang pastinya meninggalkan tanah air, keluarga dan harta benda ini dilakukan demi menjunjung perintah Allah S.W.T. Imam al-Qurțubī membahagikan hijrah kepada beberapa hukum:

a. Hijrah dari negeri yang memerangi Islam ke negeri Islam, hukumnya wajib dan fardu ain bagi setiap muslim yang terlibat.

b. Hijrah keluar dari negeri yang mengekalkan amalan bid'ah, hukumnya juga wajib. Imam Malik menegaskan, "Tidak halal untuk tinggal di bumi yang mencela golongan salaf."

c. Hijrah keluar dari negeri yang dipenuhi perkara haram, hukumnya juga wajib kerana mencari yang halal itu kewajipan setiap muslim.

d. Hijrah kerana melarikan diri dari musibah sama ada pada agama, tubuh badan, harta atau keluarga, hukumnya wajib kerana memelihara hak dan kehormatan semua yang tersebut adalah dituntut oleh Allah S.W.T ${ }^{17}$

Penghijrahan Nabi Ibrahim adalah disebabkan oleh kehilangan semua ruang kebaikan yang baginda ingin bangunkan.

${ }^{17}$ Al-Qurțubī, al-Jāmi' li Aḥkām al-Qur'ān, 5:349-350. 
Tiada lagi kebaikan untuk terus tinggal bersama kaumnya yang menolak kebaikan. Lalu baginda berhijrah demi membangunkan kebaikan dan menegakkan risalah Allah di bumi yang dijanjikan lebih banyak kebaikan dan keberkatan. Firman Allah:

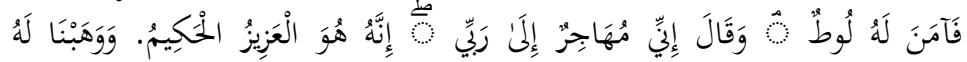

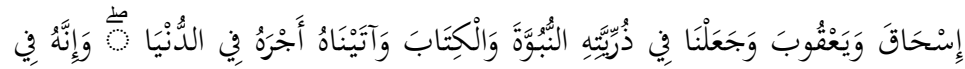

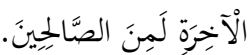

al-'Ankabūt 29: 26-27.

Terjemahan: Nabi Ibrahim berkata: "Aku akan berhijrah kepada TuhanKu, sesungguhnya Dia lah jua Yang Maha Kuasa, lagi Maha Bijaksana." Dan Kami kurniakan kepadanya: Ishak (anaknya) dan Yaakub (cucunya); dan Kami jadikan dalam kalangan keturunannya orang-orang yang berpangkat Nabi dan menerima Kitab-kitab dan Kami berikan balasannya yang baik di dunia; dan sesungguhnya dia di hari akhirat, dari kalangan orang yang soleh.

viii. Mengasingkan diri

Nabi Ibrahim turut menjauhkan diri dan berpisah dari keluarga dan kaum kerabat kerana tuntutan dakwah. Manhaj ini baginda gunakan ketika berhadapan dengan keangkuhan dan kedegilan mereka yang enggan menerima seruan dakwah yang telah disampaikan sekian lama. Tanpa mengira siapa pun mereka, termasuklah bapanya, baginda mengisytiharkan dengan jelas prinsip baginda menerusi firman Allah S.W.T.:

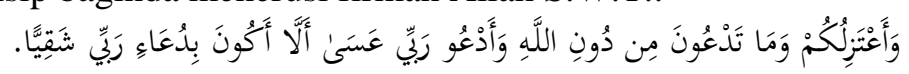

Maryam 19: 48.

Terjemahan: "Dan aku akan membawa diri meninggalkan kamu semua serta apa yang kamu sembah yang lain dari Allah; dan aku akan beribadat kepada Tuhanku dengan ikhlas; mudah-mudahan aku dengan ibadatku kepada Tuhanku itu tidak menjadi hampa (dan derhaka seperti kamu)."

Perpisahan dengan orang yang dikasihi akan mengundang ruang untuk semua pihak merenung dan berfikir dengan lebih rasional dan tenang. Inilah antara matlamat manhaj dakwah berpisah dan mengasingkan diri ini. Nabi Ibrahim terpaksa 
meninggalkan kaumnya yang engkar dan berdegil dalam kesesatan di bumi Iraq. Baginda juga sekali lagi terpaksa berjauhan dengan isterinya Hajar dan anaknya Ismail di Makkah demi menurut perintah Allah. ${ }^{18}$ Begitulah realiti perjalanan dakwah. Pelbagai manhaj perlu diaplikasikan untuk menjamin kejayaan dan memberi impak yang baik. Baginda tetap menyempurnakan perintah Allah dengan penuh keikhlasan tanpa menanti sebarang imbalan.

ix. Bersegera melaksanakan Perintah Allah

Inilah manhaj unggul Nabi Ibrahim a.s. sebagai seorang rasul yang menyampaikan risalah tuhannya. Baginda sentiasa siap siaga untuk menerima dan melaksanakan apa juga perintah Allah. Kepatuhan dan kesetiaan baginda terhadap Allah ini sewajarnya menjadi teladan kepada para daie. Firman Allah:

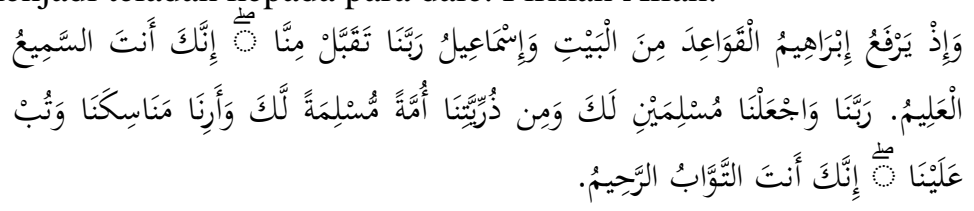

al-Baqarah 2:127-128.

Terjemahan: Dan (ingatlah) ketika Nabi Ibrahim bersamasama Nabi Ismail meninggikan binaan asas Baitullah, keduanya berdoa: "Wahai Tuhan kami, Terimalah daripada kami (amal kami); sesungguhnya Engkaulah yang Maha Mendengar lagi Maha Mengetahui. "Wahai Tuhan kami, Jadikanlah kami berdua: orang yang berserah diri kepadaMu,

${ }^{18}$ Șalāh Abd al-Fattāḥ Al-Khālidī, Al-Qașaș al-Qur'ān̄̄ , 1:372, 387. Rujuk kisah ini dalam hadith riwayat al-Bukhārī daripada Ibn 'Abbās r.a., Muḥammad bin Ismā'in̄l al-Bukhārī, Sahīh Al-Bukhārī, no hadith: 3364, Kitāb Ahādīth alAnbiyā', 4:142, nas hadith:

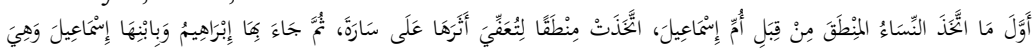

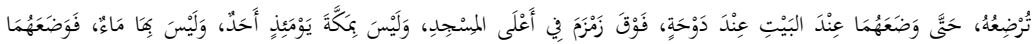

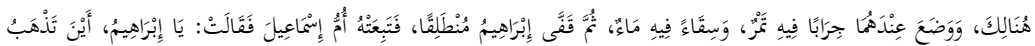

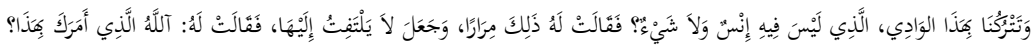

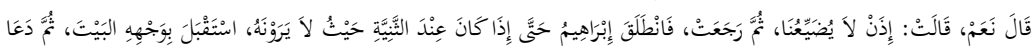

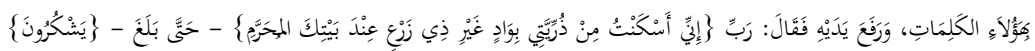
[ [ [ [ 
dan jadikanlah daripada keturunan kami: umat yang berserah diri kepadamu, dan tunjukkanlah kami syariat dan cara-cara ibadat kami, dan terimalah taubat kami,sesungguhnya Engkaulah Maha Penerima taubat lagi Maha Mengasihani."

Begitu juga ketika diperintahkan menyembelih anaknya Ismail, baginda mempamerkan ketaatan yang tidak berbelah bahagi dengan segera memberitahu kepada anaknya perihal perintah Allah yang diterimanya. Firman Allah:

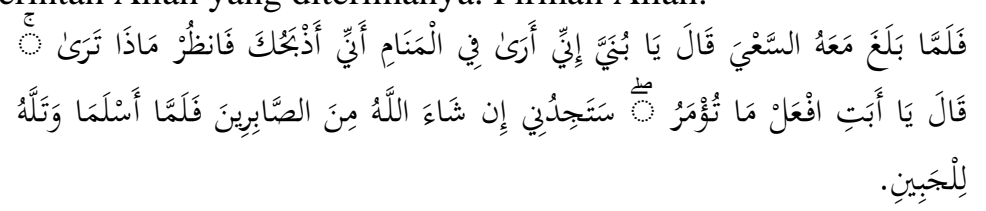

al-Ṣāffăt 37:102-103.

Terjemahan: Maka ketika anaknya itu sampai (umur yang membolehkan dia) berusaha bersama-sama dengannya, Nabi Ibrahim berkata: "Wahai anak kesayanganku! Sesungguhnya aku melihat dalam mimpi bahawa aku akan menyembelihmu; maka fikirkanlah apa pendapatmu?". Anaknya menjawab: "Wahai ayah, jalankanlah apa yang diperintahkan kepadamu; Insya Allah, ayah akan mendapati daku dari orang-orang yang sabar". Setelah mereka berdua berserah bulat-bulat (menjunjung perintah Allah itu) dan Nabi Ibrahim merebahkan anaknya dengan meletakkan mukanya di atas tompok tanah, (Kami sifatkan Ibrahim dengan kesungguhan azamnya itu telah menjalankan perintah Kami).

Ibnu Kathīr di dalam tafsirnya menyebut tentang perihal kesungguhan dan kesetiaan baginda dengan ulasan; Nabi Ibrahim a.s. telah terbukti bersungguh-sungguh menyampaikan risalah Allah dan melaksanakan apa juga perintah Allah, malah berjaya menyempurnakan semua ujian Allah terhadap baginda. ${ }^{19}$

\section{x. Sering Berdoa dan Mengadu Kepada Allah}

Berdoa dan sering mengadu kepada Allah adalah suatu keperluan dalam realiti hidup para pendakwah kerana usaha ini sentiasa berhadapan dengan tekanan dan tentangan. Nabi Ibrahim menjadikan berdoa sebagai manhaj dakwah baginda sebagai sumber inspirasi jiwa dan kekuatan iman. Di dalam Al-Qur'an

\footnotetext{
${ }^{19}$ Ismā'ī̄l Ibn Kathīr, Tafsīrr al-Qur'ān al- 'Ażīm, 7:308.
} 
banyak dirakamkan doa-doa dan rintihan baginda kepada Allah S.W.T., Antaranya ketika terasa bebanan melaksanakan perintah meninggalkan anak dan isterinya Hajar di bumi Mekah yang ketika itu gersang tanpa tumbuhan baginda berdoa:

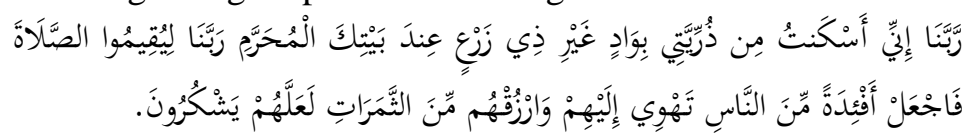

Ibrāhīm 14: 37.

Terjemahan: "Wahai Tuhan kami! Sesungguhnya aku telah tempatkan sebahagian zuriatku di sebuah lembah (Makkah) yang tiada tanaman padanya, di sisi rumahMu yang diharamkan mencerobohinya. Wahai Tuhan kami, (di situ) supaya mereka mendirikan solat. Oleh itu, jadikanlah hati sebahagian manusia tertarik kepada mereka, (supaya datang ke situ), dan kurniakanlah rezeki kepada mereka dari berbagai jenis buah-buahan dan hasil tanaman, semoga mereka bersyukur."

Antara doa baginda lagi, sebagaimana firman Allah:

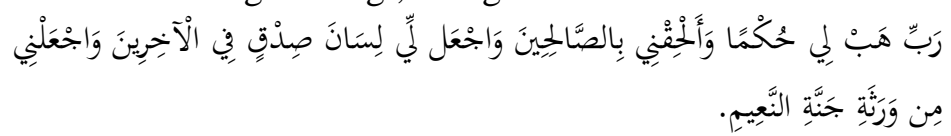

al-Shu'arāa 26: 83-85.

Terjemahan: "Wahai Tuhanku, berikanlah daku ilmu pengetahuan agama, dan hubungkanlah daku dengan orang yang soleh. Dan jadikanlah bagiku sebutan yang baik (nama yang harum) dalam kalangan orang yang datang kemudian. Dan jadikanlah daku dari orang yang mewarisi Syurga Jannatun-Na'im ."

Berdasarkan contoh-contoh doa tersebut, jelas menunjukkan kepentingan doa kepada para pendakwah. Sesungguhnya doa memainkan peranan penting dalam dakwah kerana hidayah adalah milik mutlah Allah S.W.T. Banyak ayat Al-Qur'an yang menjelaskan hakikat ini $^{20}$, justeru para pendakwah perlu sentiasa memohon dan berdoa kepada Allah. Menafikan keperluan berdoa

${ }^{20}$ Antaranya Surah Al-Qașaș 28: 56, bermaksud, "Sesungguhnya engkau (wahai Muhammad) tidak berkuasa memberi hidayah petunjuk kepada sesiapa yang engkau kasihi, tetapi Allah jualah yang berkuasa memberi hidayah petunjuk kepada sesiapa yang dikehendakiNya dan Dia lah jua yang lebih mengetahui akan orang-orang yang (ada persediaan untuk) mendapat hidayah petunjuk. 
adalah bukti sikap angkuh dan sombong. Malah tiada yang lebih buruk dari keangkuhan sebegini. ${ }^{21}$ Bagaimana mungkin seorang pendakwa yang sangat mengharapkan bantuan Allah bersikap sombong terhadapNya! Ibnu Qutaybah pula menyatakan kepentingan doa yang berperanan sebagai sumber ketenangan jiwa, kelapangan fikiran dan menghilangkan kegelisahan dengan memuatkan sebuah syair dalam kitabnya, 'Uyun al-Akhbār ${ }^{22}$ :

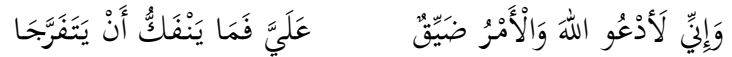

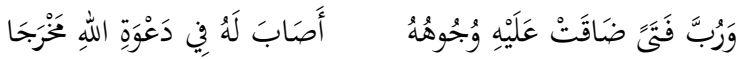

Terjemahan:

Sungguh aku pasti berdoa kepada Allah kerana urusan ini menyesakkanku. Sedangkan tiada lepas untuk bebas keluar darinya.

Berapa ramai pemuda yang kebuntuan di hadapannya. Menemui dalam doanya kepada Allah jalan keluar.

Inilah di antara manhaj yang digunakan oleh Nabi Ibrahim a.s. dalam menyampaikan seruan dakwah kepada umat manusia di zamannya sebagaimana yang dirakamkan di dalam Al-Qur'an. Sudah pasti apa juga yang dimuatkan di dalam Al-Qur'an adalah petunjuk buat umat Islam, termasuklah apa juga yang dipaparkan tentang perjalanan dakwah Nabi Ibrahim a.s. Baginda mengaplikasikan pelbagai manhaj mengikut kesesuaian dan keperluan suasana dan realiti sasaran dakwah. Kejayaan baginda melayani semua peringkat masyarakat dalam menyampaikan risalah Allah wajar dijadikan suri teladan untuk para daie di sepanjang zaman.

Manhaj yang telah dijayakan oleh Nabi Ibrahim a.s. ini adalah motode dakwah yang terbaik ketika berhadapan dengan umat manusia khasnya golongan penentang kebenaran. Baginda sentiasa memastikan dakwah dapat dijalankan dalam suasana tenang, lemah lembut, penuh ketenangan dan kasih sayang. Namun ketika perlu, baginda ternyata tetap menggunakan ketegasan dan gaya bahasa yang keras tatkala berhadapan dengan

${ }^{21}$ Muhammad bin 'Alī bin Muhạmmad bin 'Abdullah al-Yaman̄̄ al-Shawkān̄̄, Tuḥfah al-Ḍākirīn bi’Iddah al-Haṣn al-Hașīn min Kalām Sayyid al-Mursāī̄n (Beirut: Dār al-Qalam, 1984), 33.

22 'Abd Allah bin Muslim bin Qutaybah al-Daynūrī Ibn Qutaybah, 'Uyūn alAkhbār (Mesir: Dār al-Kutub al-Mișriyyah, 1925), 2:287. 
golongan yang berdegil mempertahankan kebatilan. Di samping mempelbagaikan manhaj dalam dakwah baginda juga sentiasa bertawakal dan berdoa kepada Allah SWT untuk mendapat kekuatan iman dan jiwa dalam merealisasikan tugasan dakwah yang sentiasa mencabar.

\section{Aplikasi Manhaj Dakwah Nabi Ibrahim dalam Kalangan Pendakwah Masa Kini}

Jika dirujuk kepada realiti dakwah hari ini, kita dapati beberapa manhaj dakwah Nabi Ibrahim a.s. yang dibentangkan di atas diaplikasikan dengan baik dan berkesan oleh sebahagian pendakwah masa kini. Meskipun tidak semua manhaj baginda dapat diamalkan, namun masih ada yang dapat dilaksanakan dengan baik dan berjaya.

1. Manhaj 'berlembut dalam berdakwah' terbukti sangat perlu diaplikasikan dengan baik terhadap sasaran dakwah hari ini. Lantaran sesi dialog dan debat bukan sekadar memerlukan kemantapan ilmu dan kepetahan berhujah malah ia memerlukan elemen lain yang mampu memujuk golongan yang dihadapi untuk tunduk dan akur menerima kebenaran. Para pendakwah yang mampu mengendalikan dakwah secara berlembut dan tenang akan dikenal sebagai dai yang disenangi dan mudah didekati. Perkara ini diakui oleh seorang pendakwah, Ezam Ahmad ketika membicarakan calon yang sesuai untuk berhadapan dan berdialog dengan Kassim Ahmad. Beliau mencadangkan orang yang sesuai berdebat dengannya ialah Hasrizal Abdul Jamil. ${ }^{23}$ Ini kerana beliau berupaya menangkis hujah Kassim Ahmad dari sudut sejarah, psikologi dan pemikiran di samping mengetengahkan jalan damai yang mampu memujuk Kassim Ahmad beralah secara sukarela dan memujuk hadirin yang menyebelahinya memahami hujahhujah agama.

Menurutnya lagi, hujah yang bertubi-tubi dengan dalil, tidak berkesan buat golongan ini yang cara berfikirnya berbeza. Kenyataan ini dapat dibuktikan dengan kesan dakwah yang disampaikan secara kasar dan keras gagal membuahkan hasil yang baik malah mengundang pelbagai masalah lain. Sebagai contoh,

${ }^{23}$ Ustaz Emran Ahmad, "Dua nama sesuai debat dengan Kassim Ahmad", laman sesawang Sinar Online dicapai 2 April 2014, http://www.sinarharian.com.my /karya/pendapat/dua-nama-sesuai-debat-. 
dakwah Zamihan Mohd Zin, Presiden ASWAJA, seorang penceramah yang sering mengundang kontroversi dengan gaya ceramahnya yang keras dan kasar. Ternyata manhaj sebegini tidak mengundang sebarang natijah yang baik terhadap pelbagai isu yang ditangani. Malah pada 16 Oktober, Sultan Selangor, Sultan Sharafuddin Idris Shah telah menarik balik tauliah Zamihan untuk mengajar agama di Selangor, sambil menyifatkan isi kandungan ceramah beliau berunsur rasis, kurang beradab dan melampau. ${ }^{24}$ Ditambah lagi dengan ugutan bunuh yang pernah diterimanya pada bulan Mei 2016. ${ }^{25}$

Lihat juga kemelut perbalahan yang tercetus antara beliau dengan Mohd Asri Zainal Abidin, Mufti Perlis. Pertembungan antara dua individu ini hampir mengheret mereka kepada perdebatan secara terbuka. Seluruh negara menanti dengan penuh minat detik yang dijadualkan pada 17 Februari 2016 tanpa menyedari adakah matlamat dan keperluan perdebatan sebegini selaras dengan tuntutan agama. ${ }^{26}$ Walau bagaimanapun, sehari sebelum berlangsung perdebatan tersebut, pada 16 Februari 2016, program itu dibatalkan hasil nasihat beberapa individu yang berpengaruh, antaranya Menteri di Jabatan Perdanan Menteri, Jamil Khir Baharom. ${ }^{27}$ Semua ini terjadi berpunca dari manhaj penyampaian dakwah yang tidak berlandaskan manhaj Al-Quran.

Dalam satu forum bertajuk Istilah Kafir Harbi - Masih Relevan atau Tidak $?^{28}$ sekali lagi beliau mempamerkan gaya keras dan kasar dan gagal membuahkan sebarang kebaikan dalam perbincangan tersebut, malah memaparkan imej kurang baik bagi seorang dai Islam.

2. Nabi Ibrahim juga menggunakan kaedah dakwah hari ini dengan'berhujah dengan bijak dan berani'. Manhaj ini

${ }^{24}$ Rujuk; https://www.bharian.com.my/berita/nasional/2017/10/338133/sultanselangor-berkenan-tarik-balik-tauliah-zamihan, capaian 24 Mei 2018.

${ }^{25}$ Rujuk; https://www.malaysiakini.com/news/331107, capaian 24 Mei 2018.

${ }^{26}$ Saifuddin Abdullah, "Menanti debat Asri-Zamihan", laman sesawang Sinar Online dicapai 23 Februari 2016, http://www.sinarharian.com.my/kolumnis /saifuddin-abdullah/menanti-debat-asri-zamihan-1.485179

27 Bernama, "Dr Asri, Zamihan debate unnecessary, says Jamil Khir", laman sesawang The Star Online, dicapai 23 Februari 2016, http://www.thestar.com .my/news/nation/2016/02/12/dr-asri-debate-jamil-khir/

${ }^{28}$ Forum bertajuk Istilah Kafir Harbi -Masih Relevan atau Tidak? Rujuk https://www.youtube.com/watch?v=DFObSeE5aiA 
seringkali dipamerkan oleh seorang pendakwah antarabangsa yang tersohor, Zakir Naik. Kemampuan dan kebijaksanaan beliau berhujah dan berdebat memang tidak dapat dinafikan sehingga mampu menarik ramai orang memeluk Islam setelah mendengar penjelasan dan jawapan-jawapan pertanyaan mereka. Di ruang laman youtube banyak memaparkan realiti ini dalam programprogram dakwah beliau. Antaranya slot dialog bertajuk Christian Sister Accept Islam After She Got 2 Answers, juga dialog bertajuk Indian Lady Converts To Islam After She Got Her Answer, dan Brillaint!! Dr. Zakir Naik Proved Hell \& Heaven In Two Ways. ${ }^{29}$ Begitu juga tentang keberanian menghadapi tentangan dan cabaran dalam berdakwah, beliau sentiasa tenang dan memberi penjelasan yang positif terhadap para penentang dan pihak yang menekannya. Situasi ini pula dapat disorot melalui ruang dialog bertajuk Are You Banned? Amazing Answer, Malaysia banned Zakir Naik, Why UK Government Ban You? ${ }^{30}$

3. Manhaj 'berhijrah' keluar negeri untuk berdakwah, juga dilakukan oleh beberapa orang tokoh pendakwah hari ini, antaranya Nuruddin Marbu' Al-Banjari, Habib Ali Zaenal Abidin Al-Hamid dan Abdul Somad yang meninggalkan tanahair mereka untuk berdakwah di Malaysia. Hasilnya amat baik untuk medan dakwah di negara ini dengan sambutan yang menggalakkan terhadap tokoh-tokoh dai hari ini. Realiti ini digambarkan dengan kehadiran lebih 15,000 jemaah yang memenuhi segenap ruang Masjid Sultan Salahuddin Abdul Aziz Shah, Shah Alam untuk mendengar ceramah yang disampaikan oleh pendakwah dan ulama terkenal dari Riau, Indonesia, Abdul Somad. ${ }^{31}$

Pelaksanaan manhaj dakwah yang digunakan oleh pendakwah masa kini menggambarkan manhaj dakwah Nabi

${ }^{29}$ Dialog bertajuk, Christian Sister Accept Islam After She Got 2 Answers, rujuk; https://youtu.be /T5ZISSOhbzQ, dialog bertajuk, Indian Lady Converts To Islam After She Got Her Answer, rujuk; https://youtu.be/LL-SFPRBBFw, dialog bertajuk, Brillaint!! Dr. Zakir Naik Proved Hell \& Heaven In Two Ways, rujuk; https://www.youtube.com/watch?v=hSvmlX8g3ig, semua di atas dicapai pada 23 Mei 2018.

${ }^{30}$ Rujuk laman youtube; https://youtu.be/6pWdgIoDZxM, https://youtu.be /gUHPUUmonrU, https://youtu.be/qOJMu9JGOJw, semua di atas dicapai pada 23 Mei 2018.

${ }^{31}$ Rujuk https://selangorkini.my/2018/02/masjid-negeri-full-house-demi-tazkirah -ustaz-abdul-somad-lc-m-a/ 
Ibrahim a.s. yang dipaparkan di dalam Al-Quran adalah manhaj yang tepat, berkesan dan relevan untuk diteladani oleh semua golongan pendakwah sepanjang zaman. Ia selaras dengan realiti Al-Quran sebagai pedoman utama umat Islam yang tidak ada keraguan padanya, juga petunjuk bagi sekalian orang beriman.

\section{Penutup}

Inilah manhaj-manhaj yang sewajarnya menjadi pedoman dan ikutan para daie dalam menjayakan perjuangan menyampaikan risalah Allah di muka bumiNya ini. Sesungguhnya, ketokohan baginda Nabi Ibrahim sebagai seorang rasul ulu al-azmi dan $a b b$ al-anbiy $\bar{a}$-bapa para nabi- wajar dikaji, dijadikan pedoman dan teladan oleh setiap para daie dalam berdakwah menyampaikan risalah Allah.

\section{Rujukan}

Ab. Aziz Mohd. Zin. Psikologi Dakwah. Kuala Lumpur: Jabatan Kemajuan Islam Malaysia, 1999.

Al-Khālidī, Șalāh Abd al-Fattāḥ. Al-Qașaṣ al-Quraānī, Syria: Damsyik, Dār al-Qalam, 1998.

Al-Marāghī, Aḥmad bin Mușțafā. Tafsīr Al-Marāghī. Mesir: Sharikah Maktabah wa Mațba'ah Muștafã al-Bābī Al-Ḥalabī wa Aulādihi, 1946M.

Al-Māturid̄̄, Abū Manșūr Muḥammad bin Muḥammad bin Maḥmūd. Ta'wīlāt Ahli al-Sunnah Tafsìr al-Māturīdī. Beirut: Dār al-Kutub Al-'Ilmiyah, 2005.

Al-Qazwin̄̄, Aḥmad bin Fāris. Maqāyīs al-Lughah, tahq. 'Abd alSalām Muhammad Hārūn. Beirut: Dār al-Fikr, 1979.

Al-Qurțubī, Muḥammad bin Aḥmad bin Abū Bakr. Al-Jāmi' li Ahkām al-Qur'ān. Kaherah: Dār al-Kātib al-'Arabī li alTịā'ah, 1966.

Al-Rāzī, Fakhr al-Dīn. Mafātīh al-Ghayb al-Tafsìr al-Kabīr. Beirut: Dār Ihỵā’ al-Turāth al-'Arabiyy, 1999.

Al-Shawkān̄i, Muḥammad bin 'Alī bin Muḥammad bin 'Abdullah al-Yamanī. Tuhfah al-Dhākirīn bi'Iddah al-Haṣn al-Hașinn min Kalām Sayyid al-Mursālīn. Beirut: Dār al-Qalam, 1984.

Al-Tirmidhī, Muhammad bin 'Īsā bin Sawrah bin Mūsā bin alḌaḥhạq, Abū 'Īsā, Al-Jāmi' al-Kabīr, Sunan al-Tirmidhī, Beirut: Dār al-Gharb al-Islāmī, 1998. 
Haji Abdul Malik Abdul Karim Amrullah. Tafsir al-Azhar. Singapura: 1440, Pustaka Nasional Pte. Ltd., 1990.

Ibn Ḥibbān, Muhammad Hibbān bin Aḥmad bin Ḥibbān bin Mu'adh bin Ma'bad al-Tamīmī, Abū Ḥātim, Șaḥịh Ibnu Hibbān, Beirut: Muassasah al-Risālah, 1993.

Ibn Qutaybah, 'Abd Allah bin Muslim bin Qutaybah al-Daynūrī. 'Uyūn al-Akhbār. Mesir: Dār al-Kutub al-Mișriyyah, 1925.

Muḥammad bin Ismā'in̄l al-Bukhārī, Șaḥ̄ḥ Al-Bukhārī, Beirut: Dār Țūq al-Najāh, 1422H.

Muslim bin Al-Ḥajjāj Abu Al-Ḥasan al-Qushairī al-Naisābūrī w261H, Șahīh Muslim, Taḥqīq Muḥammad Fuād 'Abd al-Bāqī, Beirut: Dār Iḥyā Al-Turāth Al-'Arabī, (t.t.)

Noresah Baharom et al. Kamus Dewan Edisi Keempat. Cet. ke-2. Kuala Lumpur: Dewan Bahasa dan Pustaka, 2007. 